\title{
Negative pressure wound therapy: clinical utility
}

This article was published in the following Dove Press journal:

Chronic Wound Care Management and Research

7 April 2015

Number of times this article has been viewed

\section{Heidi Sandoz}

Accelerate CIC, Mile End

Hospital, London, UK
Correspondence: Heidi Sandoz

Accelerate $\mathrm{CIC}$, Mile End

Hospital, Bancroft Road,

London EI 4DG London, UK

Tel +442082238331

Fax +442082238863

Email heidi.sandoz@nhs.net
Abstract: Negative pressure wound therapy (NPWT), also known as topical negative pressure therapy, has been increasingly used in health care for the management of a wide variety of wounds over the last 2-3 decades. It is an advanced therapy that can be helpful to accelerate wound healing in both acute and chronic wounds by delivering negative pressure (suction) to the wound bed. More recent advancements in the application of NPWT have provided clinicians with wider choices of utilization. There are now devices available that can deliver irrigation to the wound bed, be used for closed surgical incisions, or are disposable and highly portable. Systematic reviews considering NPWT have been published previously. These usually focus on one wound group or device and fail to offer practical clinical guidance due to the scrutiny offered to the evidence via a systematic review process. Here, an overview of the history of NPWT, the varieties of device available, their wide clinical application, and the evidence to support its use are explored in a pragmatic way.

Keywords: negative pressure, wound, incision, healing, pain

\section{History of negative pressure wound therapy}

In 1989, Chariker et al $^{1}$ published a paper describing a wound dressing technique using gauze filler, drains, and continuous closed (possibly wall or portable) suction to assist wound healing and exudate management. Papers had been published earlier than this describing similar techniques ${ }^{2-6}$ using a syringe and catheter, ${ }^{2}$ water seal drainage bottles, ${ }^{2}$ or glass chambers. ${ }^{4,5}$ In 1997, Argenta and Morykwas published two papers $^{7,8}$ describing their technique delivering the same treatment using a foam wound filler and pump, called vacuum-assisted closure (VAC) therapy. Over the next 9 years, possibly due to patents and robust marketing strategies, VAC ${ }^{\circledR}$ therapy (distributed by KCI Medical) became the only available product to deliver negative pressure wound therapy (NPWT) worldwide.

In 2006, Blue Sky Medical ${ }^{9}$ successfully challenged some of the patents held by KCI Medical and Wake Forest University, and opened up the market to alternative modes of delivering NPWT. Since that time, several manufacturers have brought competitively priced products to the market, some of which have also had patent battles in the courts with KCI Medical and Wake Forest University. ${ }^{10}$

\section{How does NPWT work?}

Through the use of a wound filler contact material (foam, gauze, or drain), negative pressure is applied directly to the wound bed using an electrically, battery, or mechanically 
powered pump. An airtight vacuum seal is required in order to achieve this. The level of negative pressure delivered to the wound may vary dependent upon manufacturer, wound type, and wound filler. Early research undertaken by Morykwas et $\mathrm{al}^{8}$ demonstrated improved blood flow to the wound with negative pressures set at higher levels. This has been both supported $^{11}$ and disputed ${ }^{12}$ in later studies.

The benefits of using NPWT include enhanced healing, ${ }^{13-15}$ management of exudate, ${ }^{14,15}$ reduced dressing changes compared with other dressings, ${ }^{16}$ reduced nurse time, ${ }^{17}$ reduced costs, ${ }^{13}$ and improved quality of life. ${ }^{13}$ Wound healing is thought to be assisted by provision of a moist environment, interstitial fluid removal, exudate removal and therefore rebalance of cytological disturbances, ${ }^{14,15}$ enhancing granulation tissue formation via mechanical stress, ${ }^{8,15}$ and promoting angiogenesis ${ }^{14}$ and enhanced tissue perfusion. ${ }^{14,15,18}$

Others have reported fluctuations in blood flow according to distance from the wound edge and the level of negative pressure applied to the wound. ${ }^{11,19,20}$ This may be a useful finding to consider when using NPWT on wounds with compromised vascularity, such as in patients with diabetic foot or lower limb arterial disease where caution may be required with use if reperfusion is diminished. ${ }^{20}$ Claims by Morykwas et $\mathrm{al}^{8}$ of a reduction in bacterial count have not been further supported by research. ${ }^{14,15}$

\section{When can NPWT be used?}

NPWT is suitable for use in all but a few wounds (including closed surgical or grafted wounds) and requires caution in others $^{21,22}$ (Table 1). There is evidence of NPWT being used with good clinical effect in a wide variety of wounds and clinical situations (Table 2).

\section{Adverse events}

As with anything in health care, the benefits of a therapy need to be balanced with any risks. There are several adverse events reported with regard to the use of NPWT, including retention of foam dressing in the wound tissue, ${ }^{22}$ perforation of blood vessels, ${ }^{22,44}$ cardiac rupture, ${ }^{45}$ and retention of liner dressings. ${ }^{46}$ Clinicians need to be both aware and mindful of the risks of these events and ensure that the patient has been fully informed.

\section{Modes of delivery of NPWT}

Since 2005, the variety of commercially available pumps delivering NPWT has expanded. Consideration of how NPWT is delivered can be divided into two categories for ease of explanation, ie, type of wound contact material used to ensure negative pressure is in contact with the wound bed and the type of pump used to deliver the negative pressure.

\section{Wound contact material}

NPWT requires a contact material to enable the negative pressure or suction from the pump to reach the wound bed. Currently, using commercially available products, this is most commonly achieved by using one (or a combination) of the following: antimicrobial gauze wound filler, foam wound filler, drains, flat dressings for incisional/superficial wounds, and exposed bowel dressings.

Selecting which contact material is used may be dependent on the available supplier and contract within the local clinical area. Much of the clinical evidence available prior to 2005 focuses on the use of foam with the KCI Medical VAC therapy pumps. However, since that time, the use of gauze filler has increased, prompting both the production

Table I Wounds where NPWT is contraindicated or caution with use is needed

\begin{tabular}{|c|c|c|c|}
\hline Contraindicated wounds & Rationale & Use with caution & Rationale \\
\hline $\begin{array}{l}\text { Wounds involving untreated } \\
\text { osteomyelitis }\end{array}$ & $\begin{array}{l}\text { If the wound closes over an } \\
\text { underlying osteomyelitis there } \\
\text { is a risk the wound will recur }\end{array}$ & Wounds with visible fistula & $\begin{array}{l}\text { Isolate fistula to prevent } \\
\text { further deterioration }\end{array}$ \\
\hline $\begin{array}{l}\text { Wounds exposing blood vessels, } \\
\text { nerves, anastomotic sites or organs, } \\
\text { or with an unexplored fistula }\end{array}$ & $\begin{array}{l}\text { Risk of rupture to blood vessel, } \\
\text { anastomotic site, or organ; } \\
\text { risk of nerve damage; risk } \\
\text { of further deterioration of fistula }\end{array}$ & $\begin{array}{l}\text { Wounds with exposed } \\
\text { bone or tendon }\end{array}$ & $\begin{array}{l}\text { Isolate bone or tendon from } \\
\text { direct pressure by protecting } \\
\text { with a liner dressing } \\
\text { to prevent drying out }\end{array}$ \\
\hline $\begin{array}{l}\text { Wounds including open } \\
\text { joint capsules }\end{array}$ & Risk of drainage of synovial fluid & $\begin{array}{l}\text { Clotting disorder } \\
\text { or anticoagulant use }\end{array}$ & Risk of bleeding \\
\hline $\begin{array}{l}\text { Skin malignancy and excised skin } \\
\text { malignancy except for palliation }\end{array}$ & $\begin{array}{l}\text { Risk of exacerbation of growth } \\
\text { of malignant cells }\end{array}$ & $\begin{array}{l}\text { Compromised microvascular } \\
\text { blood flow to the wound bed }\end{array}$ & $\begin{array}{l}\text { Risk of further compromise } \\
\text { of vascular supply }\end{array}$ \\
\hline $\begin{array}{l}\text { Wounds with necrotic tissue, } \\
\text { debride first }\end{array}$ & $\begin{array}{l}\text { NPWT will not facilitate } \\
\text { debridement of necrotic tissue }\end{array}$ & & \\
\hline
\end{tabular}

Abbreviation: NPWT, negative pressure wound therapy. 
Table 2 Published papers utilizing NPWT for a wide variety of wound types

\begin{tabular}{|c|c|c|}
\hline Reference & Wound type & Paper type \\
\hline Baharestani $\mathrm{i}^{23}$ & $\begin{array}{l}\text { Neonatal and pediatric } \\
\text { population }\end{array}$ & $\begin{array}{l}\text { A retrospective case study } \\
\text { of } 24 \text { children aged between } \\
14 \text { days and } 18 \text { years }\end{array}$ \\
\hline Butter et $\mathrm{a}^{24}$ & Pediatric population & Retrospective case review \\
\hline Binet et $\mathrm{a}^{25}$ & $\begin{array}{l}\text { Giant omphalocele } \\
\text { management }\end{array}$ & $\begin{array}{l}\text { Case study report of three } \\
\text { babies aged aged II days } \\
\text { to } 5 \text { months }\end{array}$ \\
\hline Yu et $\mathrm{a}^{26}$ & $\begin{array}{l}\text { Post-sternotomy } \\
\text { mediastinitis }\end{array}$ & Systematic review \\
\hline $\begin{array}{l}\text { Gupta } \\
\text { and Ichioka }{ }^{27}\end{array}$ & Pressure ulcers & $\begin{array}{l}\text { Literature review and case } \\
\text { studies }\end{array}$ \\
\hline Ousey et $\mathrm{a}^{28}$ & Spinal wounds & Systematic review \\
\hline Davies et $\mathrm{a}^{29}$ & Exposed brain & $\begin{array}{l}\text { Letter reporting single case } \\
\text { study }\end{array}$ \\
\hline Falagas et $\mathrm{al}^{30}$ & $\begin{array}{l}\text { Sternal wound } \\
\text { infections }\end{array}$ & Meta-analysis \\
\hline Gupta $^{31}$ & Skin graft & Literature review \\
\hline Llanos et $\mathrm{a}^{32}$ & & Randomized controlled trial \\
\hline $\begin{array}{l}\text { Sziklavari } \\
\text { et al }{ }^{33}\end{array}$ & Pleural empyema & $\begin{array}{l}\text { Retrospective case study } \\
\text { review }\end{array}$ \\
\hline $\begin{array}{l}\text { Vuerstaek } \\
\text { et a }\left.\right|^{34}\end{array}$ & Chronic leg ulcers & Randomized controlled trial \\
\hline Jeffery ${ }^{35}$ & $\begin{array}{l}\text { Severe military lower } \\
\text { limb trauma }\end{array}$ & Case studies \\
\hline $\begin{array}{l}\text { Penn-Barwell } \\
\text { et } \mathrm{al}^{36}\end{array}$ & Combat wounds & Retrospective case review \\
\hline $\begin{array}{l}\text { Noble-Bell } \\
\text { and Forbes }{ }^{37}\end{array}$ & Diabetic foot ulcer & Systematic review \\
\hline Roberts et $\mathrm{a}^{38}$ & Open abdomen & Systematic review \\
\hline Molnar et $\mathrm{al}^{39}$ & Burns & Single case studies \\
\hline $\begin{array}{l}\text { Gonzalez Alana } \\
\text { et a } \mathrm{l}^{40}\end{array}$ & Burns & Single case studies \\
\hline Stannard et $\mathrm{al}^{41}$ & $\begin{array}{l}\text { Closed incisional } \\
\text { wounds }\end{array}$ & $\begin{array}{l}\text { Literature review and case } \\
\text { studies }\end{array}$ \\
\hline Masden et $\mathrm{al}^{42}$ & & Randomized controlled trial \\
\hline Suzuki et $\mathrm{a}^{43}$ & $\begin{array}{l}\text { Surgically closed } \\
\text { wounds in open } \\
\text { fractures }\end{array}$ & Retrospective review \\
\hline
\end{tabular}

of a best practice statement ${ }^{47}$ and studies comparing gauze with foam. ${ }^{48-50}$ It has been demonstrated that gauze filler achieves the same clinical outcomes ${ }^{48,50}$ whilst reducing pain for the patient at dressing change, ${ }^{50,51}$ saving nursing time, and reducing costs. ${ }^{50}$

In a bid to find a cheaper wound contact filler, Tuncel et $\mathrm{al}^{52}$ have described similar effects using a sterilized, storebought loofah sponge when compared with foam and gauze in in vivo studies of acute wounds in rabbits. Perez et al ${ }^{53}$ also describe creating a "homemade" system to deliver negative pressure in Haiti, where funding for the commercially available systems is not available. They used the foam from a surgical hand scrub brush as the wound contact material. Both groups reported effective clinical outcomes.
Where bowel is exposed within either an intentionally laid open or a dehisced abdominal wound, ${ }^{54}$ a specialized membrane liner dressing is used in combination with either foam or gauze to prevent fistulation of the bowel. Fistula formation has been reported in 7\% of patients where NPWT has been used over an open abdomen. ${ }^{54}$

There is an absence of clinical comparative trials with regard to channel drains. However, a channel drain can be used for a tracking sinus wound of considerable depth or length. The narrow lumen of a channel drain can be inserted into sinuses with or without gauze to help facilitate closure of the sinus. The origin of the sinus should be explored ${ }^{47}$ prior to commencing NPWT via scan, ultrasound, magnetic resonance imaging, or computed tomography. This can help eliminate a deeper source for the sinus origin that may need to be resolved prior to attempting closure.

\section{Pump type}

There are currently several commercially available pumps on the market. Rather than discuss them by manufacturer, they are described here via functionality.

\section{Traditional negative pressure delivery}

These pumps can be used with gauze and/or foam filler, and may be either cumbersome or smaller and portable, commonly using a carry bag. The canisters in use with these pumps will usually hold from $300 \mathrm{~mL}$ to $1,000 \mathrm{~mL}$ of wound exudate. They are electrically powered and have a battery backup.

\section{Disposable negative pressure pumps}

These are sized to be hand-held, and are battery ${ }^{55-58}$ or mechanically powered. ${ }^{59,60}$ They may use a dressing or a canister to hold exudate. These are disposed of once therapy or dressing life is over.

\section{Negative pressure pumps \\ for surgical incision wounds}

There are two commercially available pumps $\mathrm{s}^{58,61,62}$ that use flat absorbent dressings for use directly over closed surgical wounds. These are small and easily carried pumps, and are disposable once the dressing life has expired or therapy is completed. It is not clear in the literature whether these devices reduce the incidence of surgical site dehiscence and infection. Stannard et $\mathrm{a}^{163}$ were early authors describing the use of NPWT to prevent surgical incision dehiscence and infection in patients with orthopedic trauma wounds. Their small randomized study was inconclusive. Some later 
studies have also yielded similar findings. ${ }^{42,61}$ However, larger randomized studies since have found that use of incisional NPWT has reduced infection and dehiscence rates. ${ }^{64,65}$

\section{Irrigation negative pressure pump}

There are two commercially available irrigation pumps reported in the literature ${ }^{66-70}$ that can intermittently deliver irrigation fluids to the wound with negative pressure. Various instillation fluids have been described, including insulin, ${ }^{69}$ antibiotics, ${ }^{66}$ Dakin's solution, ${ }^{68}$ and polyhexamethylene biguanide. $^{71,72}$ This technique of instilling fluids into the wound whilst intermittently delivering negative pressure has been described previously. ${ }^{73,74}$ The main outcome for this mode of delivery is prevention or eradication of infection, and it has been shown to be useful for osteomyelitis ${ }^{72}$ and to improve retention rates of infected orthopedic implants. ${ }^{71}$ A recent international consensus guideline on the use of instillation therapy offers recommendations as to suitable wound types and instillation fluids. ${ }^{75}$

\section{Adapted or "home-made" systems}

Several authors have described using the hospital central suction system ${ }^{32,53,76}$ to apply negative pressure to wounds. The cost savings in comparison with a commercial pump system are favorably portrayed.

\section{Clinical effectiveness of NPWT}

It could be argued that NPWT sees the highest number of randomized clinical trials, systematic reviews, and consensus best practice guidelines in publication than any other wound treatment modality. NPWT has been clinically evaluated and compared with other wound treatments, one NPWT wound contact material has been compared with another, the costs of delivering NPWT have been analyzed, and patientcentered outcomes such as pain have also been considered. Meta-analyzing the different controlled trials can be difficult due to the heterogeneity of the wound types studied. The methodology of some of the randomized clinical trials can be criticized; often power, blinding issues, potential bias, and randomization systems are not discussed. As such, three of four Cochrane reviews ${ }^{74,77-79}$ have been unable to recommend the use of NPWT over any other treatment modality. The fourth ${ }^{80}$ suggests that when used with the diabetic foot ulcer patient, there may be a benefit to healing and reduced risk of further amputation. However, they do recommend caution when considering the results because of the risk of bias around adequate blinding. In a recent BMJ rapid response, Tovey and Bero ${ }^{81}$ quote: "Few now support the view that the randomized controlled trial is the only meaningful research to guide rational decision-making, or that statistical significance is the only determinant of effectiveness." When considering effectiveness, the clinician must consider not just the evidence base but also take a broader view incorporating clinician experience and patient preference. When it comes to NPWT, it would seem clinicians continue to utilize this modality in many more advancing ways without what Cochrane can agree is a robust evidence base. As is often the case in medicine, NPWT was created by innovative clinicians who needed to solve a clinical problem. Commercial companies have then produced products that will deliver the innovation to a wider market. Innovative clinicians take these commercial products and adapt them to help solve a clinical problem. And so the cycle goes on. Innovative risk-taking clinicians drive medical advancement which, in turn, feeds the randomized clinical trial to prove the effectiveness of the innovation. However, lack of proof via randomized clinical trial should not then halt the use or advancement of these treatments. Lack of evidence of effect is not the same as evidence of no effect. Policy makers and budget holders need to be mindful of this chicken and egg scenario.

As this is not a systematic review of NPWT, ${ }^{13-15,28,37,49,61}$ it highlights only some of the studies that have claimed to demonstrate clinical effectiveness and/or cost-effectiveness of NPWT, without critiquing the methodology that might challenge their findings.

\section{Reduction in wound size}

NPWT using a foam contact layer has been shown to reduce open wound size and volume to a statistically significant degree when compared with alternative treatment modalities. ${ }^{53,76,82-86}$ However, in contrast, Braakenburg et al ${ }^{87}$ reported no statistical significance when compared with what they describe as modern dressings (hydrocolloid, alginate, acetic acid, and EUSOL [Edinburgh University Solution of Lime]) except within the patient population with cardiovascular disease and/or diabetes.

\section{Cost-effectiveness}

Where cost-effectiveness has been evaluated, it has been demonstrated that NPWT is more cost-effective than alternatives. ${ }^{13,88}$ However, the costs are balanced by a reduced number of dressing changes and nurse time required to change the dressings. ${ }^{13}$ To a finance director, the cost of NPWT can seem extremely high. As such, it is important to understand how reduced healing time can impact on the overall costs involved when negotiating for the use of 
NPWT in times of austerity. The larger portion of the costeffectiveness papers consider KCI Medical VAC therapy as the product of comparison. More recently, the costs of using a gauze-based system have been compared favorably with KCI Medical VAC therapy. ${ }^{50}$

\section{Foam versus gauze filler}

Studies comparing effectiveness between gauze-based and foam-based NPWT have considered the difference in healing rates, ${ }^{50}$ pain at dressing change, ${ }^{50,51}$ contraction, ${ }^{89,90}$ scar tissue depth, ${ }^{91}$ tissue formation ${ }^{91,92}$ and deformation, ${ }^{92}$ and microvascularity effect. ${ }^{19,92}$

It would seem that there is very little difference in clinical outcomes between the two types of contact media. However, it has been demonstrated that less force is required to remove the gauze medium, ${ }^{92,93}$ which may go some way to explaining the finding that patients report higher pain levels ${ }^{50,51}$ when using foam, which can allow tissue ingrowth. ${ }^{93}$ It has also been shown that the granulation tissue forming under foam is thicker with increased scarring. ${ }^{93}$ Plastic surgeons have identified this as a cause of frailer skin grafting, and as such, some have switched to using gauze to prepare a wound for skin grafting. ${ }^{93}$

\section{Level of negative pressure}

The level of negative pressure required will vary according to the manufacturer's instructions, the contact material used, and patient acceptability, but is usually between $-50 \mathrm{mmHg}$ and $-200 \mathrm{mmHg}$. For instance, gauze requires a much lower negative pressure to collapse and conform to the wound bed than a denser foam.

Initial studies ${ }^{8}$ considering the level of negative pressure required to be effective suggested that $125 \mathrm{mmHg}$ resulted in optimal blood flow. However, later studies have not been able to achieve consensus with regard to level of pressure and what effect this has on blood flow. ${ }^{11}$ Very often the level of pressure selected is guided by the manufacturer. Clinicians may decide to set pressures lower to reduce pain or higher to expedite exudate removal. ${ }^{21}$

\section{Effect of wound liners on pressure}

One study considered the effect that a wound liner contact layer may have on the level of pressure delivered to the wound bed. ${ }^{94}$ Three liners were evaluated on healthy skin, and so conclusions as to translation when using on the wounds themselves need to be drawn with caution. However, what can be concluded is that the use of Jelonet ${ }^{\circledR}$ (Smith and Nephew) adversely affects the negative pressure, thereby rendering its use impractical where negative pressures need to be achieved, but is potentially useful where structures, such as fistulas, bone, or vascular grafts, may need to be isolated from negative pressure.

\section{Using NPWT in clinical practice: decision-making and application tips}

When deciding to use NPWT, several considerations are necessary:

- Suitability of the wound for the therapy

- Risk factors and risks of harm by using the device

- Suitability of the patient for the therapy

- Which device and contact medium will best suit the clinician and patient outcomes

- What level of pressure is best for the wound and desired outcomes

- Length of time treatment is expected to be needed

- Who will manage the ongoing dressing changes and in what setting

- Use in the community

- Willingness of patient to receive the treatment.

Most wounds are suitable for the use of NPWT, taking into consideration the aforementioned contraindications. Rather than considering suitability of use by wound type, it is more reasonable to consider suitability by wound conditions. For instance, a wound with an exposed blood vessel or necrotic tissue present may be contraindicated unless the vessel can be safely protected or the necrotic tissue can be debrided. A wound too close to a functioning anus may lead to challenges gaining a secure seal, rendering NPWT impractical to use.

Of course, the wound belongs to a person, whose ability to cope with the pump and therapy also needs to be taken into consideration. ${ }^{21}$ Some questions to consider prior to commencing therapy are:

- How mobile is this person and will the pump restrict their mobility?

- How heavy will the pump be for them to carry?

- Will the therapy be used in a hospital setting or in the patient's residential setting?

- Are there any safety issues that need to be considered, for instance, trip hazards, poor vision, hearing problems, and frail or elderly living alone?

- How readily will the individual cope with any alarms and will they be able to follow processes to resolve these?

- Where pumps are owned or rented by individual organizations, how will the pump be returned to that organization when therapy is discontinued? 


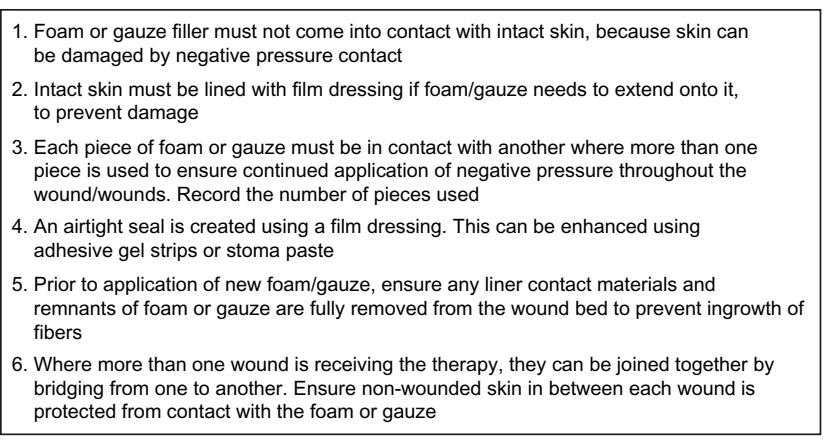

Figure I Practical tips for safe and effective application of negative pressure wound therapy.

- Does the patient have cognition and are they willing to comply with the therapy?

- How painful is the wound and dressing change? Where dressing changes are painful, nitrous oxide may reduce this, but this would need to be administered in the hospital setting as very often this is not available in the community setting.

Dressing changes will be undertaken 2-4 times per week dependent upon the contact dressing used, manufacturer guidance, exudate levels, and patient preferences.

Transition of care from the hospital to the community setting with NPWT in place requires good communication between organizations. Very often, a tissue viability nurse from each organization will be involved in this transition. Papers describing processes to aid this transition have been published previously. ${ }^{17,95}$ Accepting NPWT for use in the community setting can expedite earlier discharge from hospital and reduce the number of community nursing visits for dressing changes, both of which reduce the costs of overall care for patients with wounds that can be managed with NPWT. ${ }^{17}$

\section{Tips for successful dressings}

In order for NPWT to effectively accelerate wound healing it requires good contact with the wound bed and a vacuum

1. Where foam or gauze has been used with minimal beneficial effect,
try switching to the alternative
2. Where foam is adhering to newly growing granulation tissue and/or
causing pain on removal, switch to gauze
3. Where shaping and sculpting the foam filler may be time-consuming,
consider using gauze
4. Where narrow tracks or sinuses exist, consider using gauze or a
channel drain
5. Where mobility is important to the patient, for instance in a young
working person, consider using a smaller disposable device

Figure 2 Selecting the wound filler and pump. achieved by sealing the dressing from air leaks. There are a number of other considerations to ensure safety during therapy use (Figure 1).

\section{Wound filler and pump selection}

The selection of type of wound filler and pump may be based on several considerations (Figure 2). In some organizations, this may be limited to which system is available for use.

\section{Conclusion}

NPWT is a widely utilized treatment for many different wound types. Despite the quality of trial methodology depreciating statistically significant findings, NPWT has been shown to be effective in accelerating wound healing and reducing treatment costs. Advances in the development of NPWT products are providing clinicians with an expanding choice of therapeutic modalities to use. Further research is needed to demonstrate the effectiveness of NPWT when used to prevent surgical incision dehiscence and infection.

\section{Disclosure}

The author reports no conflicts of interest in this work.

\section{References}

1. Chariker ME, Jeter KF, Tintle TE, Bottsford JE. Effective management of incisional and cutaneous fistulae with closed suction wound drainage. Contemp Surg. 1989;34:59-63.

2. McClean WC. The role of closed wound negative pressure suction in radical surgical procedures of the head and neck. Laryngoscope. 1964;74:70-94.

3. Kostiuchenok BM, Kolker II, Karlov VA, Ignatenko SN, Muzykant LI, Samykina TD. [The vacuum effect in the surgical treatment of purulent wounds]. Vestnik Khirurgii. 1986;137:18-21. Russian.

4. Davydov YA, Malafeeva EV, Smirnov AP, Flegontov VB. [Vacuum therapy in the treatment of purulent lactation mastitis]. Vestnik Khirurgii. 1986;11:66-70. Russian.

5. Davydov YA, Larichev AB, Menkov KG. [The bacteriological and cytological assessment of vacuum therapy of purulent wounds]. Vestnik Khirurgii. 1988;10:48-52. Russian.

6. Davydov YA, Larichev AB, Menkov KG. [Concepts for clinical biological management of the wound process in the treatment of purulent wounds using vacuum therapy]. Vestnik Khirurgii. 1991;2:132-135. Russian.

7. Argenta LC, Morykwas MJ. Vacuum-assisted closure: a new method for wound control and treatment: clinical experience. Ann Plast Surg. 1997;38:563-576.

8. Morykwas MJ, Argenta LC, Shelton-Brown EI, McGuirt W. Vacuum-assisted closure: a new method for wound control and treatment: animal studies and basic foundation. Ann Plast Surg. 1997;38:553-562.

9. McClanahan and Clearman. Judge enters judgment upholding BlueSky medical verdict in wound-care patent battle. 2006. Available from: http://www.prnewswire.com/news-releases/judge-enters-judgmentupholding-bluesky-medical-verdict-in-wound-care-patent-battle56275447.html. Accessed December 23, 2014.

10. Slind-Flor V. Smith and Nephew, "Fierce Five": Intellectual Property. 2012. Available from: http://www.bloomberg.com/news/2012-08-14/ smith-nephew-fierce-five-intellectual-property.html. Accessed July 13, 2014. 
11. Borgquist $\mathrm{O}$, Anesäter E, Hedström E, Lee CK, Ingemansson R, Malmsjö M. Measurements of wound edge microvascular blood flow during negative pressure wound therapy using thermodiffusion and transcutaneous and invasive laser Doppler velocimetry. Wound Repair Regen. 2011;19:727-733.

12. Kairinos N, Solomons M, Hudson DA. The paradox of negative pressure wound therapy - in vitro studies. J Plast Reconstr Aesthet Surg. 2010;63:174-179.

13. Othman D. Negative pressure wound therapy literature review of efficacy, cost effectiveness, and impact on patients' quality of life in chronic wound management and its implementation in the United Kingdom. Plast Surg Int. 2012;2012:374398.

14. Mouës CM, Heule F, Hovius SER. A review of topical negative pressure therapy in wound healing: sufficient evidence? Am J Surg. 2011;201:544-556.

15. Schintler MV. Negative pressure therapy: theory and practice. Diabetes Metab Res Rev. 2012;28 Suppl 1:72-77.

16. Wu SC, Armstrong DG. Clinical outcome of diabetic foot ulcers treated with negative pressure wound therapy and the transition from acute care to home care. Int Wound J. 2008;5 Suppl 2:10-16.

17. Dowsett C, Davis L, Henderson V, Searle R. The economic benefits of negative pressure wound therapy in community-based wound care in the NHS. Int Wound J. 2012;9:544-552.

18. Ichioka S, Watanabe H, Sekiya N, Shibata M, Nakatsuka T. A technique to visualize wound bed microcirculation and the acute effect of negative pressure. Wound Repair Regen. 2008;16:460-465.

19. Malmsjö M, Ingemansson R, Martin R, Huddlestone E. Wound edge microvascular blood flow. Effects of negative pressure wound therapy using gauze or polyurethane foam. Ann Plast Surg. 2009;63:676-681.

20. Kairinos N, Voogd AM, Botha PH, et al. Negative-pressure wound therapy II: negative-pressure wound therapy and increased perfusion. Just an illusion? Plast Reconstr Surg. 2009;123:601-612.

21. Henderson V, Timmons J, Hurd, T, Deroo K, Maloney S, Sabo S. NPWT in everyday practice made easy. Wounds Int. 2010;1(5).

22. US Food and Drug Administration. Update on serious complications associated with negative pressure wound therapy systems. FDA Safety Communication; 2011. Available from: http://www.fda.gov/ MedicalDevices/Safety/AlertsandNotices/ucm244211.htm. Accessed July 6, 2014.

23. Baharestani M. Use of negative pressure wound therapy in the treatment of neonatal and pediatric wounds: a retrospective examination of clinical outcomes. Ostomy Wound Manage. 2007;53:75-85.

24. Butter A, Emran M, Al-Jazaeri, Ouimet A. Vacuum assisted closure for wound management in the pediatric population. J Pediatr Surg. 2006;41:940-942.

25. Binet A, Gelas T, Jochault-Ritz S, et al. Giant omphalocele treatment: a multicentre study. J Plast Reconstr Aesthet Surg. 2013;66 e373-e375.

26. Yu AW, Rippel RA, Smock E, Jarral OA. In patients with poststernotomy mediastinitis is vacuum-assisted closure superior to conventional therapy? Interact Cardiovasc Thorac Surg. 2013;17:861-866.

27. Gupta S, Ichioka S. Optimal use of negative pressure wound therapy in treating pressure ulcers. Int Wound J. 2012;9 Suppl 1:8-16.

28. Ousey KJ, Atkinson RA, Williamson JB, Lui S. Negative pressure wound therapy (NPWT) for spinal wounds: a systematic review. Spine J. 2013;13:1393-1405.

29. Davies CR, Mitsala G, Malcolm G, Orlando A. Safe application of topical negative pressure dressings to exposed brain before definitive reconstruction. Plast Reconstr Aesthet Surg. 2014;67: e204-e205.

30. Falagas ME, Tansarli GS, Kapaskelis A, Vardakas KZ. Impact of vacuum-assisted closure (VAC) therapy on clinical outcomes of patients with sternal wound infections: a meta-analysis of non-randomized studies. PLoS One. 2013;8:e64741.

31. Gupta S. Optimal use of negative pressure wound therapy for skin grafts. Int Wound J. 2012;9 Suppl 1:40-47.
32. Llanos S, Danilla S, Barraza C, et al. Effectiveness of negative pressure closure in the integration of split thickness skin grafts. Ann Surg. 2006;244:700-705.

33. Sziklavari Z, Grosser C, Neu R, et al. Minimally invasive vacuumassisted closure therapy in the management of complex pleural empyema. Interact Cardiovasc Thorac Surg. 2013;17:49-53.

34. Vuerstaek JD, Vainas T, Wuite J, Nelemans P, Neumann MH, Veraart JC. State-of-the-art treatment of chronic leg ulcers: a randomized controlled trial comparing vacuum-assisted closure (VAC) with modern wound dressings. J Vasc Surg. 2006;44:1029-1038.

35. Jeffery SL. Advanced wound therapies in the management of severe military lower limb trauma: a new perspective. ePlasty. 2009;9:e28.

36. Penn-Barwell JG, Fries CA, Street L, Jeffery S. Use of topical negative pressure in British servicemen with combat wounds. ePlasty. 2011;11:e35.

37. Noble-Bell G, Forbes A. A systematic review of the effectiveness of negative pressure wound therapy in the management of diabetes foot ulcers. Int Wound J. 2008;5:233-242.

38. Roberts DJ, Zygun DA, Grendar J, et al. Negative-pressure wound therapy for critically ill adults with open abdominal wounds: a systematic review. J Trauma Acute Care Surg. 2012;73:629-639.

39. Molnar JA, Simpson JL, Voignier DM, Morykwas MJ, Argenta LC. Management of an acute thermal injury with subatmospheric pressure. J Burns Wounds. 2005;4:e5.

40. González Alaña I, Torrero López JV, Martín Playá P, Gabilondo Zubizarreta FJ. Combined use of negative pressure wound therapy and Integra ${ }^{\circledR}$ to treat complex defects in lower extremities after burns. Ann Burns Fire Disasters. 2013;26:90-93.

41. Stannard JP, Gabriel A, Lehner B. Use of negative pressure wound therapy over clean, closed surgical incisions. Int Wound J. 2012;9 Suppl 1: 32-39.

42. Masden D, Goldstein J, Endara M, Xu K, Steinberg J, Attinger C. Negative pressure wound therapy for at-risk surgical closures in patients with multiple comorbidities: a prospective randomized controlled study. Ann Surg. 2012;255:1043-1047.

43. Suzuki T, Minehara A, Matsuura T, Kawamura T, Soma K. Negative-pressure wound therapy over surgically closed wounds in open fractures. J Orthop Surg. 2014;22:30-34.

44. Mirsaidi N. Negative pressure wound therapy: use with care. Nursing. 2010;40:64

45. Thorsteinsson DT, Valsson F, Geirsson A, Gudbjartsson T. Major cardiac rupture following surgical treatment for deep sternal wound infection. Interact Cardiovasc Thorac Surg. 2013;16:708-709.

46. Tan J, Matteucci P, Tzafetta K. An unusual complication of TNP. J Wound Care. 2009;1:332-333.

47. Best Practice Statement: Gauze-based Negative Pressure Wound Therapy. Aberdeen, Scotland: Wounds UK; 2008.

48. Borgquist O, Gustafsson L, Ingemansson R, Malmsjö M. Micro- and macromechanical effects on the wound bed of negative pressure wound therapy using gauze and foam. Ann Plast Surg. 2010;64: 789-793.

49. Birke-Sorensen H, Malmsjo M, Rome P. Evidence-based recommendations for negative pressure wound therapy: treatment variables (pressure levels, wound filler and contact layer). Steps towards an international consensus. J Plast Reconstr Aesthet Surg. 2011;64: S1-S16.

50. Dorafshar AH, Franczyk M, Gottlieb LJ, Wroblewski KE, Lohman RF. A prospective randomized trial comparing subatmospheric wound therapy with a sealed gauze dressing and the standard vacuum-assisted closure device. Ann Plast Surg. 2012;69:79-84.

51. Fraccalvieri M, Ruka E, Bocchiotti MA, Zingarelli E, Bruschi S. Patient's pain feedback using negative pressure wound therapy with foam and gauze. Int Wound J. 2011;8:492-499.

52. Tuncel U, Turan A, Markoc F, Erkorkmaz U, Elmas C, Kostakoglu N. Loofah sponge as an interface dressing material in negative pressure wound therapy: results of an in vivo study. Ostomy Wound Manage. 2014;60:37-45. 
53. Perez D, Bramkamp M, Exe C, von Ruden C, Ziegler A. Modern wound care for the poor: a randomized clinical trial comparing the vacuum system with conventional saline-soaked gauze dressings Am J Surg. 2010;199:14-20.

54. National Institute for Health and Care Excellence. Negative pressure wound therapy for the open abdomen: NICE interventional procedure guidance (IPG 467). Available from: https://www.nice.org.uk/guidance/ ipg467. Accessed December 22, 2014.

55. van den Bulck R, Siebers Y, Zimmer R, Acton C, Janzing H, Lang W. Initial clinical experiences with a new, portable, single-use negative pressure wound therapy device. Int Wound J. 2013;10:145-151.

56. Hudson DA, Adams KG, Van Huyssteen A, Martin R, Huddleston EM. Simplified negative pressure wound therapy: clinical evaluation of an ultraportable, no-canister system. Int Wound J. May 7, 2013. [Epub ahead of print.]

57. Armstrong DG, Andros G. Use of negative pressure wound therapy to help facilitate limb preservation. Int Wound J. 2012;9 Suppl 1:1-7.

58. Payne C, Edwards D. Application of the single use negative pressure wound therapy device (PICO) on a heterogeneous group of surgical and traumatic wounds. ePlasty. 2014;14:e20.

59. Hutton DW, Sheehan P. Comparative effectiveness of the SNaPTM wound care system. Int Wound J. 2011;8:196-205.

60. Armstrong DG, Marston WA, Reyzelman AM, Kirsner RS. Comparative effectiveness of mechanically and electrically powered negative pressure wound therapy devices: a multicenter randomized controlled trial. Wound Repair Regen. 2012;20:332-341.

61. Stannard JP, Gabriel A, Lehner B. Use of negative pressure wound therapy over clean, closed surgical incisions. Int Wound J. 2012;9 Suppl 1: 32-39.

62. Colli A, Camara ML. First experience with a new negative pressure incision management system on surgical incisions after cardiac surgery in high risk patients. J Cardiothorac Surg. 2011;6:160.

63. Stannard JP, Robinson JT, Anderson ER, McGwin G Jr, Volgas DA, Alonso JE. Negative pressure wound therapy to treat hematomas and surgical incisions following high-energy trauma. $J$ Trauma. 2006;60:1301-1306.

64. Stannard JP, Volgas DA, McGwin G III, et al. Incisional negative pressure wound therapy after high-risk lower extremity fractures. J Orthop Trauma. 2012;26:37-42.

65. Adogwa O, Fatemi P, Perez E, et al. Negative pressure wound therapy reduces incidence of post-operative wound infection and dehiscence after long-segment thoracolumbar spinal fusion: a single institutional experience. Spine J. 2014;14:2911-2917.

66. Gabriel A, Shores J, Heinrich C, et al. Negative pressure wound therapy with instillation: a pilot study describing a new method for treating infected wounds. Int Wound J. 2008;5:399-413.

67. Gabriel A. Integrated negative pressure wound therapy system with volumetric automated fluid instillation in wounds at risk for compromised healing. Int Wound J. 2012;9 Suppl 1:25-31.

68. Giovinco NA, Bui TD, Fisher T, Mills JL, Armstrong DG. Wound chemotherapy by the use of negative pressure wound therapy and infusion. ePlasty. 2010;10:e9.

69. Scimeca CL, Bharara M, Fisher TK, Kimbriel H, Mills JL, Armstrong DG. Novel use of insulin in continuous-instillation negative pressure wound therapy as "wound chemotherapy". J Diabetes Sci Technol. 2010;4:820-824.

70. Scimeca CL, Bharara M, Fisher TK, Giovinco N, Armstrong DG. Novel use of doxycycline in continuous-instillation negative pressure wound therapy as "wound chemotherapy" Foot Ankle Spec. 2010;3: 190-193.

71. Lehner B, Fleischmann W, Becker R, Jukema GN. First experiences with negative pressure wound therapy and instillation in the treatment of infected orthopaedic implants: a clinical observation study. Int Orthop. 2011;35:1415-1420.

72. Timmers MS, Graafland N, Bernards AT, Nelissen RG, van Dissel JT, Jukema GN. Negative pressure wound treatment with polyvinyl alcohol foam and polyhexanide antiseptic solution instillation in posttraumatic osteomyelitis. Wound Repair Regen. 2009;17:278-286.
73. Fleischmann W, Russ M, Westhauser A, Stampeh1 M. [Vacuum sealing as carrier system for controlled local drug administration in wound infection]. Unfallchirurg. 1998;101:649-654. German.

74. Usupov YN, Yepifanov MV. [Active wound drainage]. Vestnik Khirurgii. 1987;4:42-45. Russian.

75. Kim PJ, Attinger CE, Steinberg JS, et al. Negative-pressure wound therapy with instillation: international consensus guidelines. Plast Reconstr Surg. 2013;132:1569-1579.

76. Mody GN, Nirmal IA, Duraisamy S, Perakath BA. Blinded, prospective, randomized controlled trial of topical negative pressure wound closure in India. Ostomy Wound Manage. 2008;54:36-46.

77. Ubbink DT, Westerbos SJ, Evans D, Land L, Vermeulen H. Topical negative pressure for treating chronic wounds. Cochrane Database Syst Rev. 2008;3:CD001898.

78. Webster J, Scuffham P, Sherriff KL, Stankiewicz M, Chaboyer WP. Negative pressure wound therapy for skin grafts and surgical wounds healing by primary intention. Cochrane Database Syst Rev. 2012;4:CD009261.

79. Dumville JC, Munson C. Negative pressure wound therapy for partialthickness burns. Cochrane Database Syst Rev. 2012;12:CD006215.

80. Dumville JC, Hinchliffe RJ, Cullum N, et al. Negative pressure wound therapy for treating foot wounds in people with diabetes mellitus. Cochrane Database Syst Rev. 2013;10:CD010318.

81. Greenhalgh T, Howick J, Maskrey N. Rapid response to evidence based medicine: a movement in crisis? BMJ. 2014;348:g3725.

82. Etoz A, Ozgenel Y, Ozcan M. The use of negative pressure wound therapy on diabetic foot ulcers: a preliminary controlled trial. Wounds. 2004:16:264-269

83. Mouës CM, Vos MC, van den Bemd GJ, Stijnen T, Hovius SE. Bacterial load in relation to vacuum-assisted closure wound therapy: a prospective randomized trial. Wound Repair Regen. 2004;12:11-16.

84. Armstrong DG, Lavery LA. Negative pressure wound therapy after partial diabetic foot amputation: a multicentre, randomised controlled trial. Lancet. 2005;366:1704-1710.

85. Etoz A. Negative pressure wound therapy on diabetic foot ulcers. Wounds. 2007;19:250-254.

86. Blume PA, Walters J, Payne W, Ayala J, Lantis J. Comparison of negative pressure wound therapy using vacuum-assisted closure with advanced moist wound therapy in the treatment of diabetic foot ulcers. Diabetes Care. 2008;31:631-636.

87. Braakenburg A, Obdeijn MC, Feitz R, van Rooij IA, van Griethuysen AJ, Klinkenbijl JH. The clinical efficacy and cost effectiveness of the vacuum-assisted closure technique in the management of acute and chronic wounds: a randomized controlled trial. Plast Reconstr Surg. 2006;118:390-397.

88. de Leon JM, Barnes S, Nagel M, Fudge M, Lucius A, Garcia B. Costeffectiveness of negative pressure wound therapy for postsurgical patients in long-term acute care. Adv Skin Wound Care. 2009;22:122-127.

89. Malmsjö M, Ingemansson R, Martin R, Huddleston E. Negativepressure wound therapy using gauze or open-cell polyurethane foam: similar early effects on pressure transduction and tissue contraction in an experimental porcine wound model. Wound Repair Regen. 2009;17:200-205.

90. Anesäter E, Borgquist O, Hedstrom E, Waga J, Ingemansson R, Malmsjo M. The influence of different sizes and types of wound fillers on wound contraction and tissue pressure during negative pressure wound therapy. Int Wound J. 2011;8:336-342.

91. Fraccalvieri M, Zingarelli E, Ruka E, et al. Negative pressure wound therapy using gauze and foam: histological, immunohistochemical and ultrasonography morphological analysis of the granulation tissue and scar tissue. Preliminary report of a clinical study. Int Wound J. 2011;8:355-364.

92. Malmsjö M, Gustafsson L, Lindstedt S, Gesslein B, Ingemansson R. The effects of variable, intermittent, and continuous negative pressure wound therapy, using foam or gauze, on wound contraction, granulation tissue formation, and ingrowth into the wound filler. ePlasty. 2012;12:e5. 
93. Borgquist $\mathrm{O}$, Gustafsson L, Ingemansson R, Malmsjö M. Tissue ingrowth into foam but not into gauze during negative pressure wound therapy. Wounds. 2009;21:302-309.

94. Jones SM, Banwell PE, Shakespeare PG. Interface dressings influence the delivery of topical negative pressure therapy. Plast Reconstr Surg. 2005;116:1023-1028.
95. Guy H, Grothier L. Using negative pressure therapy in wound healing Nurs Times. 2012;108:16.

\section{Publish your work in this journal}

Chronic Wound Care Management and Research is an international, peer reviewed, open access, online journal publishing original research, reviews, editorials, and commentaries on the causes and management of chronic wounds and the major issues related to chronic wound management. Topics also include chronic wounds as comorbidities to other conditions, patient adherence to therapy, and the economic burden of chronic wounds. The manuscript management system is completely online and includes a very quick and fair peer review system, which is all easy to use. Visit http://www.dovepress.com/testimonials.php to read real quotes from published authors.

Submit your manuscript here: http://www.dovepress.com/chronic-wound-care-management-and-research-journal 